\title{
CHESS-PLAY AS THE EFFECTIVE TECHNIQUE IN FOREIGN LANGUAGE TRAINING
}

\author{
Joanna Harazińska ${ }^{1}$, Anna Harazińska ${ }^{2}$ \\ ${ }^{1} J a n$ Kochanowski University Kielce, \\ Foreign Languages Department in Piotrków Trybunalski, Poland \\ phone : +48 4473274 00, e-mail: j.harazinska@unipt.pl \\ ${ }^{2}$ Coordinator of the Project "Education through Chess in School", \\ Polish Chess Federation, 00-697 Warsaw, Al. Jerozolimskie 49 \\ phone: +48 22 4282376, e-mail: a.harazinska@pzszach.pl
}

\begin{abstract}
The present article is based on the results of research with reference to the children in the age of 7-10 years. That is why the conclusions are not applicable for analyzing the glottodidactic process in teaching of adults. The authors have elaborated the very concrete data resulting from the experimental implementing of chess play into the primary school curriculum and observing the mental and physical growing of the children involved. The results obtained as well as the conclusions and assumptions are analyzed on the ground of the project implemented on the national level of Polish educational system.
\end{abstract}

Key words: foreign language training, chess-play, effective technologies of foreign language teaching.

\section{INTRODUCTION}

The project "Education through Chess in School" is organized and guided by Polish Chess Federation in cooperation with the provincial chess unions and local authorities. It is addressed to primary schools for pupils from classes I-III. Key partners for Polish Chess Federation include Ministry of National Education and Ministry of Sport \& Tourism.

The idea to introduce chess in schools as an effective form of supporting education was founded in Polish chess environment many years ago. The direct stimulus for the start of implementation came from the European Parliament in 2012 when declaration calling on all member states of the European Union to introduce education of chess in educational settings was signed.

Polish Chess Federation has developed a coherent program of teaching chess in primary schools:

1. Prepared the set of textbooks written by Magdalena Zielińska - "Let's play chess" for children as well as teaching materials for the teachers [7]

2. Organizes 72-hour courses for teachers preparing them to teach basics of chess in classes I-III (in the vast majority of cases the costs are covered by local authorities or schools)

3. Organizes additional training courses and methodological conferences.

4. Equips schools with fifteen chess sets and demonstration chessboard - all free of charge.

5. Offers help in the organization of chess events by schools participating in the project.

6. Runs the website (www.szachywszkole.pl) and a group "Education through chess in schools" on Facebook. Provides separate phone number (+48 2242823 76) and e-mail: szachywszkole@pzszach.org.pl for informational purposes.

7. In "Mat" - journal published by the Polish Chess Federation there is a special insert 


\section{ART'TE $Y$}

Ipplied Resseirlores in Technics, Technologies and Educration

Journal of the Faculty of Technics and Technologies, Trakia University https://sites.google.com/a/trakia-uni.bg/artte/

dedicated to chess in schools.

8. The plans for the nearest future include publishing the methodical guide for teachers, lesson scenarios and work cards for students, as well as creating web-based platform used for education of teachers and the exchange of experience between schools.

9. The elaboration of the program to continue learning chess in classes IV-VI.

10. Every year organizes the huge Final Tournament for children participating in the project.

11. Project evaluation is conducted by research centers of leading Polish Universities they study effects of chess classes on general development and school achievements of students.

Obligations of schools which sign the declaration of voluntary accession to the Project:

1. Learning chess as a form of compulsory classes must be carried out in at least one class of early education for the minimum of one hour per week for at least two years.

2. Chess Classes may be conducted only by teachers with a certificate of completion of the 72-hour course organized by the Polish Chess Federation.

3. The school certificate should include the descriptive assessment of the activities of chess.

4. School board and parents must agree on the participation of students in the evaluation of the Project.

\section{EXPOSE}

The first 152 schools joined the project "Education through Chess in School" in 2013. In the school year $2014 / 2015$ our project involved more than 300 schools. In the $2015 / 2016$ project covered over 600 schools, in the 2016/2017 - over 900 and 2017/2018 - over 1100 schools in all 16 provinces. Over 4.000 teachers shared chess knowledge with at least 50000 students.

The aforementioned figures show that the range of expansion of the project "Education through Chess in School" is very wide. Constantly increasing number of schools and local governments interested in this initiative. Polish Chess Federation is organizing news conferences throughout the country.

The last year's training-methodical conference in Warsaw held on $18^{\text {th }}-20^{\text {th }}$ May 2017 , already had an international character. Both the Polish and the Foreign speakers (coming from USA, Sweden, Germany, Spain, Denmark and France) took part in that conference, which was attended in total by 170 people - school directors and teachers.

The final tournament held on $3^{\text {th }}$ June 2017 in Warsaw, gathered 750 children participating in the project.

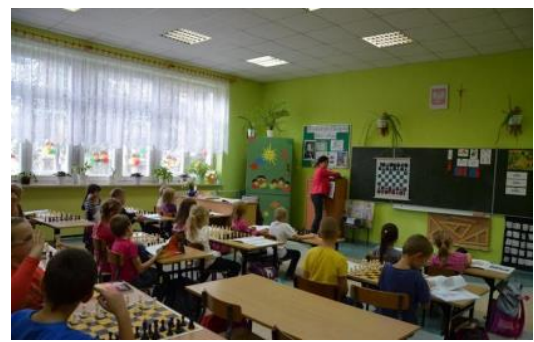

Figure 1. Chess lesson in Primary School in Małkinia Poland

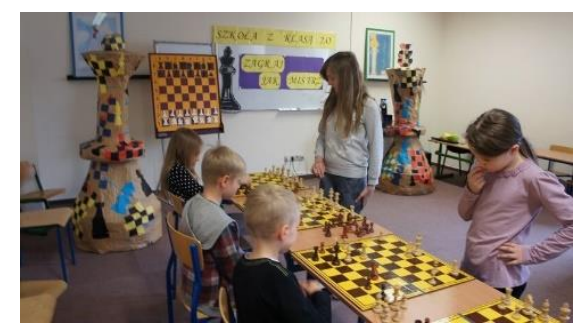

Figure 2. Chess simultanous game in Primary School 353 in Warsaw 


\section{AR'TIE Ipplied Researleches in Technics, Technologies and Eductation Journal of the Faculty of Technics and Technologies, Trakia University https://sites.google.com/a/trakia-uni.bg/artte/}

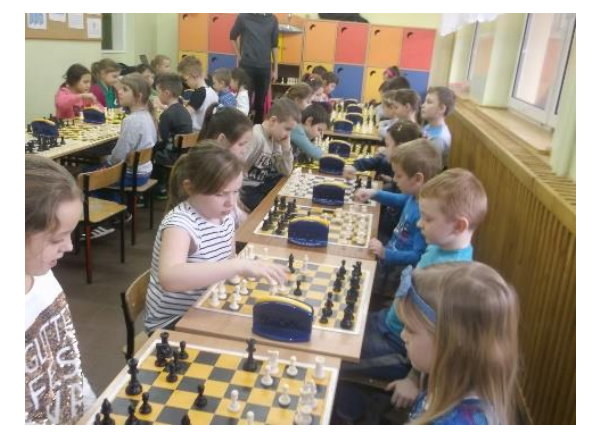

Figure 3. Chess tournament in Primary School in Włoszakowice

The positive influence of playing chess on the general intellectual growth of children is actually well known and acknowledged by many scientists and chess-trainers. $[1,4,5]$.

The Polish experiment proved once more the statement about following positive results for young pupils to be true:

1) cognitive abilities - the eagerness for learning new methods of "fighting, being interested in chess-play history,

2) mathematical skills - better understanding of system, developing of abstractive thinking,

3) emotional development - training of patience, ability of fighting to achieve concrete goals,

4) socialization process - respect towards an opponent, cooperation with a group (for instance when playing in a school team),

5) self-development, creativity.

The main result is however, the achieving of some levels of the fundamental idea of the effective learning process presented by D. Kolb and elaborated by B. Juch [3] known as CLP (Circle Learning Process).

The authors of the present article like many other researchers are aware of the fact, that CLP is only some ideal learning by doing philosophy. In the matter of fact there does not exist any technology, method or technics, which could be completely applicable to the given way via the whole circle.

In spite of it we can consider that even the chess-playing technique is one of those very close to passing almost all the gates and barriers of the learning circle: thinking-addressingdoing-reflecting. That way is relevant to any learned subject. If so, it is possible to hypothesize about the real positive influence of chess-playing on the language teaching and learning level.

\subsection{Influence of playing chess on foreign language skills}

The responsible scientific research needs the description of criteria used for the discours to be explained. With regard to that condition sine qua non the authors appointed herewith the features building the inside structure of the linguistic talent. In our opinion, based on working with and observing about 4000 learners, the linguistic gifted children have some "collection" of talents including following:

- mathematical talent,

- musical talent,

- openness, communication abilities, extravert personality,

- cognitive abilities - good memory, intellectual eagerness for getting any new information, erudition,

- developed, expanded imagination,

- high skills in using mother tongue (incl. rich vocabulary),

- general emotional and physical conditions like patience, resilience. IRTIIE Vol. 5, No. 3, 2017 ISSN 1314-8788 (print), ISSN 1314-8796 (online), doi: 10.15547/artte.2017.03.012 


\section{ART'TE $Y$}

Ipplied Resseirrches in Technicis, Technologies and Eductition

Journal of the Faculty of Technics and Technologies, Trakia University https://sites.google.com/a/trakia-uni.bg/artte/

The authors of the present article do not aim to explain hereby in details the abovementioned features that should be subject to some separate research. We concentrate here on the possible positive influence of chess playing on the given features.

The most prospective result which has the biggest potential power for accelerating the child's learning abilities is the growth of the mathematical skills. In foreign languages, training that level of abilities is deeply connected with the very important understanding and using the language as the concrete system, in accordance with the structural approach. Children who are capable of the high level mathematical performance understand the grammatical rules and use them better than average pupils, they construct and reconstruct sentences as well as complicated texts quicker and in more correct form.

It is therefore obvious that playing chess has in that case the direct positive influence on the foreign language training as a very effective teaching technique. How does it work with reference to the above mentioned abilities?

The researchers emphasize the big role of playing chess in developing imagination. From the linguistic point of view, that ability is crucial for developing speaking skills. The importance of including imagination in linguistic performance (esp. in exercises like telling stories) is essential for the educators who often have to face the cute problem of "SMS-language" used in mother tongue. The speech barrier comes from an impossibility of formulating longer speech or describing pictures and life events. The rich imagination plays therefore a very important role and thus the importance of using chess play is very high.

Another important advantage of playing chess is the fact that this kind of activity supports children's' socialization and consequently their emotional power. In other words, the children are not afraid of speaking foreign language with their friends as they develop their own resistance to stress and become more open and friendly. They develop their own individual, stronger personality. On the other hand, playing in the same team creates very often the children's esprit de corps, which directly encourages the linguistic working in teams, constructing dialogues et cetera.

Finally yet importantly, we have to point out the positive influence on the small child's patience and physical resistance. Last years in Polish pedagogical discourse and practice we have had to handle with some new "fashion". The followers of some popular theory of education are convinced that learning for small children should be nice, uncomplicated like some kind of a "never-ending" story of joy. However, the school tasks are not always simple and the pupil must be patient, consequent and ready to "fight" with the task, not giving up. That kind of patience is particularly welcome while making translation tasks. They are not always simple, many of them seem to be rather tiring or sometimes even boring but they have to be completed and here we have once more to deal with role of chess playing.

\section{CONCLUSIONS}

1. The experiment of introducing chess in Polish primary schools and the research directed on using chess as supportive technique in foreign language training has presented the very important role of that technique for better educational success of the children in the age of $7-10$.

2. Playing chess has direct positive influence on growing linguistic abilities and skills of children.

3. It is to emphasize, that the children - participants of the regular chess-play lessons conducted at their schools would in the future make the real progress especially in using grammar, in speaking and being active in general communication process.

4. The topic is prospective, the research has to be continued especially for taking feedback for comparative study esp., for concrete period of time as well as analyzing other phenomena (Other age groups? Boys versus girls? Influence on translating abilities?).

IRITIE Vol. 5, No. 3, 2017 ISSN 1314-8788 (print), ISSN 1314-8796 (online), doi: 10.15547/artte.2017.03.012 


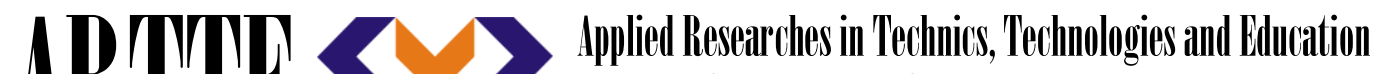 Journal of the Faculty of Technics and Technologies, Trakia University https://sites.google.com/a/trakia-uni.bg/artte/}

5. It is evident, that not all of the above mentioned talents and abilities can be developed by implementing the presented technique, for instance we have not noticed any direct influence on musical talent. Despite it, the success is obvious, even if in not with reference to all above presented requirements.

Actually, the child given by all mentioned features is simply the linguistic genius, while usually we have to deal with an average child learning the foreign language.

\section{REFERENCES}

[1] Frydman, Marcel, Lynn, Richard: The general intelligence and spatila abilities of gifted young Belgian chess players. British Journal of Psychology, May 1992, Vol. 83, No.2. Avaiable:http://onlinelibrary.wiley.com/doi/10.1111/j.2044-8295.1992.tb02437.x/abstract.

[2] Harazińska J., Nowe metody kształcenia menedżerów oświaty w Polsce i ich związek z teorią kształcenia in: Goriszowski W., Harazińska J., Kowolik P. Menedżeryzm oświatowy w warunkach transformacji ustrojowej w Polsce., Piotrków Trybunalski 1995, p.47-58.

[3] Juch B., Personal development: theory and practice in management training. John Wiley and Sons Ltd. 1983.

[4] Modzelan A. Osiągniecia szkolne uczniów objętych programem nauki gry w szachy w trzech pierwszych latach nauczania w szkole podstawowej $\mathrm{nr} 13 \mathrm{w}$ Gorzowie Wielkopolskim, Gorzów Wielkopolski 2002 [online]. Available: http://mkarasinski.pl/_cms/files/A_Modzelan_Praca_magisterska.pdf.

[5] Przewoźnik J, Edukacja przez szachy w szkole. Presentation at conference for teacher and educational trainers. Puławy, Poland, 20-22.02.2015 [online]. Available: http://janprzewoznik.pl/artykuly/pulawy_konferencja.php.

[6] Rosholm M. and others. Your move: The effect of chess on mathematics test scores. Edited by Lutz Jaencke.

[7] Zielińska M. Grajmy w szachy. Part 1, 2, 3. Polish Chess Federation 2014. 